\title{
Peranan Akuntansi Sektor Publik Terhadap Efektivitas Pengelolaan Pendapatan dan Biaya Pada Enhaii Hotel Bandung
}

\author{
Nor Ismawanto Choirudin* \\ Sekolah Tinggi Pariwisata Bandung, Indonesia \\ Email: norismanto@stp-bandung.ac.id
}

\begin{abstract}
The development of hospitality services is growing rapidly, along with the marry role of investor in the development of the service is no exception to the government, the mechanism of the implementation of hotel financial management in addition managed by the private sector is also managed by the public or government sectors, but the nature and characteristics are different. The purpose of public sector organizations is motivated nonprofit while the private sector is profitable. Sources of public sector financing are derived from taxes, corporate profits of SOEs / SOEs, etc. while private sector financing comes from owner's capital, retained earnings, bank loans, and so on. The pattern of public sector responsibility to the public and the parliament while the private sector is accountable to shareholders, owners and creditors. The organizational structure of the public sector is bureaucratic, rigid and hierarchical while the private sector is flexible. Characteristics of the public sector budget are open to the public while the private sector is closed to the public. Accounting system used public sector cash accounting while private sector accrual accounting. Based on the above, the purpose of this study is to find out how: (1) implementation of public sector accounting role in Enhaii Hotel; (2) implementation of revenue and cost management effectiveness at Enhaii Hotel; and (3) role of public sector accounting on effectiveness Revenue management and fees at Enhaii Hotel. The research methodology applied is qualitative research method with case study at Enhaii Hotel Bandung, data collecting technique is done by observation, interview, document and bibliography, while the model of analysis used is Miles and Huberman model that is data reduction, data display, and data verification. The results of the discussion show that the role of public sector accounting on the effectiveness of revenue and cost management is still less than optimal, this is because it is limited by binding rules, the arrangement of types and sales tariff has been regulated by the government so that income must be deposited to the state treasury as Non-Tax State Revenues (PNBP) And the use of operational costs based on the government budget listed in the List of Budget Implementation (DIPA) STP Bandung because Enhaii Hotel is part of the STP Bandung unit.
\end{abstract}

Keywords: Public Sector Accounting, Revenue and Cost

\section{Abstrak}

Perkembangan layanan perhotelan berkembang pesat, seiring dengan peran mengawinkan investor dalam pengembangan layanan tidak terkecuali pemerintah, mekanisme implementasi manajemen keuangan hotel selain dikelola oleh sektor swasta juga dikelola oleh sektor publik atau pemerintah, tetapi sifat dan karakteristiknya berbeda. 1. Tujuan organisasi sektor publik dimotivasi nirlaba sementara sektor swasta menguntungkan. 2. Sumber pembiayaan sektor publik berasal dari pajak, laba perusahaan BUMN / BUMN, dll. Sedangkan pembiayaan sektor swasta berasal dari modal pemilik, laba ditahan, pinjaman bank, dan sebagainya. 3. Pola tanggung jawab sektor publik kepada publik dan parlemen sementara sektor swasta bertanggung jawab kepada pemegang saham, pemilik dan kreditor. 4. Struktur organisasi sektor publik bersifat birokratis, kaku dan hierarkis sedangkan sektor swasta fleksibel. 5. Karakteristik anggaran sektor publik terbuka untuk umum sementara sektor swasta tertutup untuk umum. 6. Sistem akuntansi menggunakan akuntansi kas sektor publik sedangkan akuntansi sektor swasta akrual. Berdasarkan hal di atas, tujuan dari penelitian ini adalah untuk mengetahui bagaimana: (1) penerapan peran akuntansi sektor publik di Hotel Enhaii; (2) penerapan pendapatan dan efektivitas manajemen biaya di Enhaii Hotel; dan (3) peran akuntansi sektor publik pada efektivitas Manajemen pendapatan dan biaya di Enhaii Hotel. Metodologi penelitian yang digunakan adalah metode penelitian kualitatif dengan studi kasus di Enhaii Hotel Bandung, teknik pengumpulan data dilakukan dengan observasi, wawancara, dokumen dan daftar pustaka, sedangkan model analisis yang digunakan adalah model Miles dan Huberman yaitu reduksi data, penyajian data, dan verifikasi data. Hasil diskusi menunjukkan bahwa peran akuntansi sektor publik pada efektivitas pendapatan dan manajemen biaya masih kurang optimal, hal ini karena dibatasi oleh aturan

* Corresponding author

Received: January 01, 2018; Revised: March 01, 2018; Accepted: June 01, 2018 


\begin{abstract}
yang mengikat, pengaturan jenis dan tarif penjualan telah diatur oleh pemerintah. sehingga pemasukan harus disetor ke kas negara sebagai Penerimaan Negara Bukan Pajak (PNBP) Dan penggunaan biaya operasional berdasarkan anggaran pemerintah tercantum dalam Daftar Implementasi Anggaran (DIPA) STP Bandung karena Enhaii Hotel merupakan bagian dari STP Unit Bandung.
\end{abstract}

Kata kunci: Akuntansi Sektor Publik, Pendapatan dan Biaya

\title{
A. PENDAHULUAN
}

Sektor pariwisata di Indonesia saat ini mengalami perkembangan yang signifikan, perkembangan pariwisata tersebut membawa dampak yang sangat baik bagi fasilitas lainnya terutama akomodasi. Akomodasi dengan kata lain adalah hotel, hotel dimanfaatkan bagi orang-orang yang sedang berlibur berhari-hari sebagai sarana untuk menginap. Berdasarkan pendapat yang kemukakan oleh Kementerian Kebudayaan dan Pariwisata Republik Indonesia (Menbudpar, 2010) bahwa hotel adalah suatu bangunan atau sebagian daripadanya yang khusus disediakan untuk setiap orang agar dapat menginap dan makan serta memperoleh pclayanan dan fasilitas lainnya dengan pembayaran atau mempunyai restoran yang berada di bawah manajemen hotel tersebut."

Hotel merupakan salah satu bidana usaha jasa yang memiliki kontribusi pendapat cukup besar, terbukti banyak investor-investor yang menginvenstasikan dananya ke dunia perhotelan, tidak terkecuali pemerintah. Instansi pemerintah atau sektor publik sangat betininat dan tertarik untuk membangun, mengembangkan, dan mengelola fasilitas perhotelan, hal ini dikarenakan dapat memberikan kontribusi pendapatan bagi pemerintah sebaaai Pendapatan Negara Bukan Pajak (PNBP).

Pemerintah mengatur operasional hotel dengan menerbitkan beberapa peraturanperaturan yang mengatur skema operasional hotel, salah satunya adalah Landasan dasar pengelolaan operasional hotel yang dikelola oleh pemerintah atau scktor publik adalah dengan terbitnya Peraturan Pemcrintah Republik Indonesia Nomor 9 Tahun 2015 Tentang Jenis dan Tarif Atas Jenis Penerimaan Negara Bukan Pajak Yang Berlaku Pada Kementerian Pariwisata, yaitu basil penjualan wajib disetor ke kas negara sebagai PNBP, sedangkan biaya operasional diatur dalam Anggaran Pendapatan dan Belanja Negara yang dituangkan dalam Daftar Isian Pelaksanaan Anggaran (D1PA).

Sistem pengelolaan keuangan negara berdasarkan kepada proses dan pola akuntansi sektor publik, akuntansi sektor publik merupakan bidang keilmuan yang saat ini sedang menjadi perhatian khusus pemerintah, terbukti dengan banyaknya perubahan dan perbaikan sistem pengelolaan yang mencakup sistem akuntansi manajemen, akuntansi keuangan, perencanaan keuangan dan pembangunan serta sistem pengawas, pengendalian dan pemeriksaan serta berbagai kebijakan-kebijakan yang berlaku di negara ini. Sistem pengelolaan akuntansi sektor publik lebih menitikberatkan kepada nirlaba (fzonproft) atau tidak mencari keuntungan berbeda dengan pengelolaan akuntansi sektor swasta yang lebih menitikberatkan pada keuntungan atau laba (profit).

Mardiasmo (2009:2) mengemukakan pengertian akuntansi sektor publik dari sudut pandang ilmu ekonomi, bahwa "Sektor publik dapat dipahami sebagai suatu entitas yang aktivitasnya berhubungan dengan usaha untuk menghasilkan barang dan pelayanan publik dalam rangka memenuhi kebutuhan dan hak publik." Fungsi dan karakteristik akuntansi sektor publik hampir mirip tetapi berbeda dengan sektor swasta sedangkan konsumsi akuntansi sektor publik lebih menitikberatkan kepada pemenuhan kebutuhan dan hak publik dalam mengasilkan jasa atau barang dan pelayanan. 
Secara teori Sifat dan karakteristik aktivitas akuntansi sektor publik memiliki tujuan yang terarah terhadap pencapaian hasil (outcome) yang berbeda dengan tujuan akuntansi sektor swasta, perbedaan tersebut diakibatkan karena perbedaan pengaruh lingkungan. Mardiasmo (2009:7) mengungkapkan perbedaan tersebut adalah sebagai berikut:

"Perbedaan sifat dan karakteristik sektor publik denaan sektor swasta dapat dilihat dengan membandingkan beberapa hal, yaitu:

1 Tujuan organisasi.

2 Sumber pembiayaan.

3 Pola pertanggungjawaban.

4 Struktur organisasi.

5 Karakteristik anggaran.

6 Stakeholder yang dipengaruhi, dan

7 Sistem akuntansi yang digunakan.

Tabel 1. Perbedaan Antara Sifat dan Karakteristik Organisasi Sektor Publik den an Sektor Swasta

\begin{tabular}{|c|c|c|}
\hline Perbedaan & Sektor Publik & Sektor Swasta \\
\hline Tujuan organisasi & Nonprofit motive & Profit motive \\
\hline $\begin{array}{l}\text { Sumber } \\
\text { pembiayaan }\end{array}$ & $\begin{array}{l}\text { Pajak, retribusi, utang, obligasi } \\
\text { pemerintah,laba } \\
\text { BUMN/BUMD, penjualan } \\
\text { asset Negara, dsb }\end{array}$ & $\begin{array}{l}\text { Pembiayaan internal: modal } \\
\text { sendiri, laba ditahan, penjualan } \\
\text { aktiva. } \\
\text { Pembiayaan eksternal: utang }\end{array}$ \\
\hline $\begin{array}{l}\text { Pola pertanggung- } \\
\text { jawaban }\end{array}$ & $\begin{array}{l}\text { Pertanggungjawaban kepada } \\
\text { masyarakat (publik) dan }\end{array}$ & $\begin{array}{l}\text { Pertanggungjawaban kepada } \\
\text { pemegang saham dan kreditor. }\end{array}$ \\
\hline $\begin{array}{l}\text { Struktur } \\
\text { organisasi }\end{array}$ & Birokrasi, kaku, dan hierarkis & Fleksibel: datar, piramid, lintas \\
\hline $\begin{array}{l}\text { Karakteristik } \\
\text { anggaran }\end{array}$ & Terbuka untuk publik & Tertutup untuk publik. \\
\hline $\begin{array}{l}\text { Sistem akuntansi } \\
\text { yang digunakan }\end{array}$ & Cash accounting & Accrual accounting \\
\hline
\end{tabular}

Sumber: Mardiasmo, 2009: halaman 8

Berdasarkan sifat dan karakteristik pada tabel 1, maka akuntansi sektor publik lebih menekankan kepada pola benefit karena tidak mencari keuntungan (nonprofit) dan pertanggungjawabannya pada masyarakat atau publik dengan pola birokrasi dan pada penerimaan atau pengeluaran secara tunai semata yang sangat terikat dengan peraturan dan perundang-undangan yang dikclola dan dikeluarkan oleh pemerintah daerah maupun pemerintah pusat, sangat berbeda sekali dengan sektor swasta yang memiliki pola profit atau mencari keutungan yang lebih leluas dalam pencapaian pendapatan dan penggunaan dana operasional.

Akuntansi sektor publik memiliki peran penting dalam kelancaran operasional suatu organisasi yang dikelola oleh instansi pcmerintah, terutama dalam hal cfektivitas pengelolaan penerimaan dan 
pengeluaran, artinya adalah pengelolaan penerimaan dan pengeluaran yang dikelola sektor publik hams memberikan basil guna, hasil manfaat, yang dapat memberikan pcncapaian tujuan yang diinginkan.

Efektivitas merupakan kemampuan organisasi dalam melaksanakan kegiatannya agar tujuan yang diinginkan tercapai, dengan didasarkan pada tingkat prestasi balk dan jaminan mutu yang dipertahankan. Efektivitas dijadikan alat ukur bagi suatu organisasi dalam pencapaian tujuannya, terutama organisasi yang berhubungan dengan sector publik, dengan berbagai aturan dan perundang-undangan yang berlaku maka pelaksanaan pengelolaan kegiatan sektor publik harus terlaksana dengan baik.

Pendapatan merupakan arus masuk kegiatan penjualan produk yang dihasilkan sebagai penambahan modal atau kenaikan ekuitas. Kieso, Warfield dan Weygantd $(2011 ; 955)$ mendefinisikan pendapatan adalah "arus masuk bruto dari manfaat ekonomi yang timbul dari aktivitas normal entitas selama suatu periode, jika arus masuk tersebut mengakibatkan kenaikan ekuitas yang tidak berasal dari kontribusi penanaman modal." Sedangkan biaya merupakan pengeluaran yang atau pengorbanan karena diakibatkan adanya kegiatan operasional. Ahmad (2012:22) menyebutkan bahwa "Biaya adalah pengeluaran- pengeluaran atau nilai pengorbanan untuk memperoleh barang atau jasa yang berguna untuk masa yang akan datang, atau mempunyai manfaat melebihi satu periode akuntansi."

Sekolah Tinggi Pariwisata Bandung merupakan sekolah kedinasan yang berorientasi pendidikan yang memiliki beberapa fasilitas praktek sebagai bagian untuk mengasah kemampuan dan keterampilan mahasiswanya, salah satu fasilitas tersebut adalah fasilitas akomodasi atau hotel dengan nama Enhaii Hotel. Fasilitas Enhaii hotel tersebut disamping merupakan laboratorium praktek mahasiswa juga merupakan bagian dari potensi penambahan pendapatan yaitu dengan mengkomersilkan fasilitas tersebut kepada pihak luar yaitu dengan menjual fasilitas kamar serta makanan dan minuman dengan mentaati peraturan yang diterbitkan pemerintah terutama Kementerian Pariwisata, dari hasil penjualan tersebut maka Enhaii Hotel diharapkan dapat memberikan kontribusi pendapatan bagi pemerintah yaitu berupa pendapatan negara bukan pajak (PNBP).

Pendapatan dalam sektor publik diatur menurut Peraturan Pemerintah No. 24 tahun 2005 tentang Standar Akuntansi Pemerintahan, bahwa "pendapatan adalah semua penerimaan rekening kas umum Negara/daerah yang menambah ekuitas dana lancar dalam periode tahun anggaran yang bersangkutan yang menjadi hak pemerintah, dan tidak perlu dibayar kembali." Pemerintah mengubah peraturan sehelumnya menjadi Peraturan Pemerintah No. 71 Tahun 2010 tentang Standar akuntansi Pemerintah, dengan peraturan tersebut maka pemerintah membagi definisi pendapatan ke dalam 2 bagian yaitu :

1. Pendapatan-LO adalah hak pemerintah pusat/daerah yang diakui sebagai penambah ekuitas dalam periode tahun anggaran yang bersangkutan dan tidak perlu dibayar kembali.

2. Pendapatan-LRA adalah semua penerimaan Rekening Kas Umum NegaralDaerah yang menambah Saldo Anggaran Lebih dalam periode tahun anggaran yang bersangkutan yang menjadi hak pemerintah, dan tidak perlu dibayar kembali oleh pemerintah.

Sedangkan pengelolaan pendapatan yang berlaku pada Kementcrian Pariwisata diatur dalam Peraturan Pemerintah Republik Indonesia Nomor 9 Tahun 2015 tentang Jenis dan Tarif atas Jenis Penerimaan Negara Bukan Pajak (PNBP).

Mengacu kepada peraturan tersebut di atas maka Pengelolaan pendapatan Enhaii Hotel wajib disetor ke kas Negara yaitu sebagai setoran Penerimaan Negara Bukan Pajak (PNBP), dalam hal ini Enhaii Hotel tidak dapat mengelola secara sendiri hasil dari penjualan produk-produk yang didapat. 
Biaya sektor publik merupakan biaya yang dikeluarkan berdasarkan peraturan dan perundang-undangan pemerintah, sebagai penurunan manfaat potensi jasa. Biaya atau beban atau dapat disebut sebagai belanja. Peraturan pemerintah Nomor 71 tahun 2010 tentang Standar Akuntansi Pemerintah mendefinisikan beban dan belanja sebagai berikut :

1. Belanja adalah semua pengeluaran dari Rekening Kas Umum Negara/Daerah yang mengurangi Saldo Anggaran Lebih dalam periode tahun anggaran bersangkutan yang tidak akan diperoleh pembayarannya kembali oleh pemerintah.

2. Beban adalah penurunan manfaat ekonomi atau potensi jasa dalam periode pelaporan yang menurunkan ekuitas, yang dapat berupa pengeluaran atau konsumsi aset atau timbulnya kewajiban.

Berdasarkan definisi tersebut di atas, maka belanja dan beban merupakan pengeluaran yang dikelola pemerintah sebagai konsumsi aktivitas suatu organisasi publik yang dikeluarkan dari rekening kas umum Negara sesuai dengan anggaran dan belanja negara.

Pemerintah mengatur biaya sektor publik dalam anggaran pcndapatan dan belanja Negara (APBN) yang diatur dalam PMK No. 190/PMK.05/2012 tentang Daftar isian Pelaksanaan Anggaran (DIPA), disebutkan bahwa "DIPA adalah dokumen pelaksanaan anggaran yang digunakan sebagai acuan pengguna anggaran dalam melaksanakan kegiatan pemerintah sebagai pelaksanaan APBN."

Sumber dana kegiatan pengelolaan Enhaii Hotel agar dapat berkesinambungan maka unit Enhaii Hotel yang merupakan bagian unit laboratorium Sekolah Tinggi Pariwisata Bandung menetapkan anggaran belanja atau kcluaran atau biaya sebagai dana atau biaya operasional sehari-hari yang menjadi satu kesatuan dalam Daftar Isian Pelaksanaan Anggaran (DIPA), sehingga proses dan mekanisme penggunaan anggaran tersebut hams mengikuti peraturan yang ditetapkan pemerintah melalui persetujuan Pejabat Pembuat Komitmen (PPK) dan Kuasa Pengguna Anggaran (KPA).

Pendapatan yang wajib disetor ke kas negara sebagai penerimaan negara bukan pajak dan biaya operasional yang harus melalui prosedur birokrasi, hal ini mengakibatkan pelaksanaan operasional Enhaii Hotel kurang optimal dan terkendala dalam ranah persaingan dengan hotel sekitarnya.

\section{B. METODE}

Metode penelitian merupakan metode ilmiah dalam suatu penelitian untuk mendapatkan data yang otentik terkait gejala-gejala dan fenomena yang terjadi berdasarkan tujuan dan kegunaan. Darmadi (2013:153) mengemukakan tentang metode penelitian bahwa, "Metode penelitian adalah suatu cara ilmiah untuk mendapatkan data dengan tujuan kegunaan tertentu. Cara ilmiah berarti kegiatan penelitian itu didasarkan pada ciri-ciri keilmuan yaitu rasional, empiris, dan sistematis."

Perspektif pendekatan penelitian yang digunakan peneliti adalah pendekatan penelitian deskriptif kualitatif, deskriptif dalam hal pengumpulan informasi data tentang gejala atau keadaan penelitian yang dilakukan sedangkan kualitatif merupakan proses dan prosedur dalam penelitian yang merupakan hasil dari analisis yang menghasilkan data deskriptif yang merupakan hasil narasi dari audien yang diamati yang bersifat populasi atau sampel.

Metode kualitatif menitikberatkan kepada fenomena yang dialami oleh subjek penelitian yaitu berupa attitude, motivasi, tindakan dan lain lain dalam bentuk yang diamati adalah berupa kata-kata, bahasa dan narasi lainnya. Lexy J. Moleong (2012:6) mengungkapkan tentang metode penelitian kualitatif adalah "penelitian yang bermaksud untuk memahami fenomena tentang a pa yang dialami subjek penelitian misalnya perilaku, persepsi, motivasi, tindakan dan lain lain 
secara holistik, dan dengan cara deskripsi dalam bentuk kata-kata dan bahasa, pada suatu konteks khusus yang alamiah dan dengan memanfaatkan berbagai metode ilmiah."

Teknik pengumpulan yang dilakukan adalah dengan cara langsung dan tidak langsung kepada pihak-pihak yang merupakan sumber data, yaitu berupa dokumen- dokumen dan literatur atau referensi lainnya, untuk menunjang kelancaran penelitian dalam hal keabsahan data, teknik pengumpulan data yang peneliti lakukan berupa observasi, wawancara, dokumen triangulasi dan studi pustaka.

Observasi dalam Sugiyono (2013:145) adalah bahwa "observasi merupakan suatu proses yang kompleks, suatu proses yang tersusun dari berbagai proses biologis dan psikologis. Dua diantara yang terpenting adalah proses-proses pengamatan dan ingatan." Dalam hal ini peneliti melakukan pengamatan terhadap proses kegiatan akuntansi sektor publik yang dilaksanakan oleh pihak Enhaii Hotel, yaitu mengamati data-data dan dokumen yang berhubungan dengan pendapatan dan biaya sektor publik.

Wawancara menurut Sugiyono (2013:237) adalah sebagai teknik pengumpulan data apabila peneliti ingin melakukan studi pendahuluan untuk menemukan permasalahan yang harus diteliti." Peneliti melakukan teknik wawancara dengan pihak manajemen Hotel Enhaii untuk mengetahui permasalahan yang terjadi terhadap pengelolaan yang telah dilaksanakan herdasarkan akuntansi sektor publik.

Dokumentasi menurut Sugiyono (2013:240) adalah sebagai berikut bahwa:

"Dokumen merupakan catatan peristiwa yang sudah berlalu. Dokumen bisa berbentuk tulisan, gambar, atau karya-karya monumental dari seorang. Dokumen yang berbentuk tulisan misalnya catatan harian, sejarah kehidupan (life histories), cerita, biografi, peraturan, kebijakan." Berdasarkan hal tersebut maka peneliti mcngumpulkan data berupa dokumen yang berhubungan dengan pengelolaan sektor publik berupa peraturan-peraturan, undang-undang, kebijakan dan dokumen yang menggambarkan proses atau alur kegiatan akuntansi sektor publik.

Menurut Sugiyono (2013:241) "Triangulasi diartikan sebagai teknik pengumpulan data yang bersifat menggabungkan dari berbagai teknik pengumpulan data dan sumbcr data yang telah ada." Dalam hal ini peneliti melakukan pengumpulan data dengan cara menggabungkan seluruh sumber data yang didapat berupa basil observasi, wawancara dan seluruh dokumen lainnya, sekaligus data yang dikumpulkan dapat diuji kredibilitasnya.

Studi pustaka adalah bagian dari proses penelitian, tanpa studi pustaka penelitian yang dilakukan sangat tidak akan akurat keabsahannya. Studi pustaka merupakan literatur yang sangat penting bagi peneliti, dengan memahami literatur yang berkaitan dengan penelitian, maka memudahkan bagi peneliti dalam melakukan suatu analisa dan pengujian keabsahan data. Sugiyono (2013:291) mengemukakan bahwa "studi kepustakaan berkaitan dengan kajian teoritis dan referensi laun yang terkait dengan nilai, budaya, dan nonna yang berkembang pada situasi sosial yang diteliti."

Analisis data yang dilaksanakan dalam penelitian kualitatif ini dilakukan pada saat peneliti mulai merencanakan penelitian dilapangan diawali dengan proses sebelum ke lapangan sampai dengan selesai dilapangan. Dalam hal ini peneliti melakukan analisis data dilapangan dengan menggunakan Model Miles and Huberman, model ini lebih menitikberatkan pada interaktif dalam aktivitas penelitian kualitatif yang berlangsung sampai kondisinya menjadi jenuh. Miles and Huberman (1984) dalam Sugiyono (2013:246) mengemukakan bahwa "aktivitas dalam analisis data kualitatif dilakukan secara interaktif dan berlangsung secara terus menerus sampai tuntas, sehingga datanya sudah jenuh. Aktivitas dalam analisis data, yaitu data reduction, data display dan conclusion drawing/verificasition. 


\section{Reduksi data (data reduction)}

Reduksi data merupakan salah satu model analisis yang digunakan untuk merangkum dan memilih data yang dihasilkan saat dilapangan, agar dapat memudahkan peneliti dalam memfokuskan data-data yang penting. Sugiyono (2013:247) mengemukakan bahwa "Reduksi data berarti merangkum, memilih hal-hal yang pokok, memfokuskan pada hal-hal yang penting, dicari tema dan polanya." Berdasarkan hal tersebut di atas maka peneliti mengumpulkan, memilih dan memfokuskan data-data yang dihasilkan, data yang direduksi berupa akuntansi sektor publik terhadap efektivitas pengelolaan pendapatan dan biaya pada Enhaii Hotel.

\section{Penyajian data (data display)}

Display data atau penyajian data yang dilakukan berupa uraian singkat, gambar, hubungan antara katagori, alur, dan sebagainya yang serupa, dengan ketentuan data tersebut telah direduksi. Sugiyono (2013:249) mengemukakan pendapat yang disampaikan oleh Miles and Huberman, yaitu bahwa "the most frequent form of display data for qualitative research data in the past has been narrative text." Yaitu bentuk yang paling sering menampilkan data untuk data penelitian kualitatif dimasa lalu yang bersifat naratif. Berd asarkan hal tersebut di atas, maka peneliti melakukan penyajian data dengan menampilkan sifat narafit, agar dapat dipahami dan dimengerti, berupa data keuangan tentang pengelolaan pendapatan dan biaya sektor publik pada Enhaii Hotel.

\section{Penarikan kesimpulan dan verifikasi (conclusion drawing and verification)}

Penarikan kesimpulan dan verifikasi adalah langkah berikutnya setelah proses reduksi data dan penyajian data dilakukan. Menurut Miles dan Huberman dalam Sugiyono (2013:252) bahwa "langkah ke tiga dalam analisis data kualitatif adalah penarikan kesimpulan dan verifikasi yaitu kesimpulan awal yang dikemukakan masih bersifat sementara, dan akan berubah bila tidak diketemukan bukti-bukti yang kuat yang mendukung pada tahap pengumpulan data berikutnya_" Peneliti dalam hal ini melakukan penarikan kesimpulan dan verifikasi terhadap bukti-bukti yang berhubungan dengan peranan akuntansi sektor publik terhadap efektivitas pengelolaan pendapatan dan biaya pada Enhaii Hotel.

Enhaii Hotel merupakan hotel yang dikelola berbeda dengan hotel lainnya, Enhaii Hotel merupakan bagian unit dari struktur organisasi Sekolah Tinggi Pariwisata Bandung, Sekolah Tinggi Pariwisata Bandung merupakan perguruan tinggi yang sekarang merupakan unit pelaksana teknis (UPT) dari Kementrian, sebagai perguruan tinggi yang bergerak dibidang pendidikan pariwisata, khususnya pendidikan vokasional dan akademik, maka salah satu kekuatan Sekolah Tinggi Pariwisaata Bandung terletak pada kualitas, untuk menjamin kualitas yang baik maka dibutuhkan sarana dan prasaran pendidikan yang dikembangkan sesuai dengan tujuan institusional dan diharapakan dapat meningkatkan kualitas mahasiswa serta mampu memberikan dukungan bagi proses pendidikan vokasional tersebut, maka sarana dan prasarana yang dibutuhkan salah satunya adalah penyediaan sarana akomodasi (lodging) dengan fasilitas lainnya diantaranya restoran, ruang rapat dan lain lain yang memadai sehingga dapat atau mampu mengakomodir kebutuhan Sekolah Tinggi Pariwisata Bandung terutama jurusan perhotelan yang bersifat praktikum hotel, sehingga mahasiswa memiliki kemampuan dan terlatih dalam melakukan kegiatan dilingkungan industri hotel pada umumnya.

Seiring dengan berjalannya waktu kebutuhan sarana praktekpun bertambah, maka pada tahun 1980-an STP Bandung yang pada saat itu namanya NHI Bandung telah menyusun studi kelayakan 
(feasibility study) sebuah hotel dan sekitar tahun 2005 telah berdiri sebuah Hotel untuk keperluan praktek mahasiswa, hotel tersebut merupakan revitalisasi asrama putri menjadi sebuah hotel praktek, awalnya hotel ini bernama hotel STPB yang kemudian beralih nama menjadi Hotel Enhaii. Keberadaan Hotel Enhaii khusus sebagai sarana praktek mahasiswa Sekolah Tinggi Pariwisata Bandung dan menjadi bagian Unit dalam organisasi Sekolah Tinggi Pariwisata Bandung, dan pada tanggal 17 Maret 2006 hotel praktek Enhaii diresmikan oleh Menteri Pariwisata, Seni dan Budaya yang saat itu di jabat oleh Ir. Jero Wacik, SE.

Kegiatan dan aktivitas Enhaii Hotel praktek ini melibatkan dosen sebagai tenaga instruktur dan mahasiswa sebagai peserta didik khususnya bagi Jurusan Perhotelan Sekolah Tinggi Pariwisata Bandung serta khalayak umum sebagai tamu hotel atau yang menggunakan fasilitas hotel praktek.

Jenis dan tarif yang berlaku pada Enhaii Hotel diatur dalam Peraturan Pemerintah Republik Indonesia Nomor 9 Tahun 2015 tentang Jenis dan Tarif Penerimaan Negara Bukan Pajak (PNBP) yang berlaku pada Kementerian Pariwisata yang didalamnya mengatur tentang tarif pendapatan penjualan kamar dan penjualan makanan minuman.

\section{HASIL PEMBAHASAN}

\section{Pelaksanaan Akuntansi Sektor Publik}

Pembahasan basil pcnelitian tentang pelaksanaan akuntansi sektor publik pada Enhaii Hotel adalah sebagai berikut :

1. Tujuan kegiatan pada Enhaii Hotel bermotifkan nonprofit (nirlaba), Prosedur operasional Enhaii Hotel berdasarkan Peraturan Pemerintah Republik Indonesia, basil penjualan kamar dan penjualan makanan minuman tidak dikelola secara langsung tetapi hams disetor ke kas Negara sebagai Penerimaan Negara Bukan Pajak (PNBP). Sedangkan biaya operasional Enhaii Hotel dialokasikan pada Anggaran Pemerintah yaitu dalam Daftar Isian Pelaksanaan Anggaran (DIPA) STP Bandung, sehingga untuk mempertemukan pendapatan dan biaya (matching principles) tidak terlaksana dengan baik atau optimal.

2. Sumber pendanaan biaya operasional hotel hersumber dari pemerintah, dalam hal ini mekanisme pengajuan biaya operasional sesuai prosedur yang telah ditetapkan oleh peraturan pemerintah melalui kewenangan PPK dan KPA sebagai pejabat penguna anggaran.

3. Pertanggungjawaban kegiatan operasional Enhaii Hotel dipertanggung- jawabkan kepada masyarakat dan parlemen (DPR), Enhaii Hotel adalah bagian dari unit STP Bandung sehingga pertanggungjawaban langsung kepada Manajemen STP Bandung.

4. Struktur Organisasi Enhaii Hotel bersifat birokrasi dan kaku, Enhaii Hotel merupakan bagian dari unit STP Bandung maka struktur organisasi terbatas dan menginduk pada Struktur Organisasi STP Bandung, seperti misalkan jabatan tertinggi Enhaii Hotel tidak dipegang oleh General Manager (GM) tetapi oleh Kepala Unit.

5. Karakteristik anggaran terbuka untuk publik, karena anggaran Enhaii Hotel adalah bagian dari Anggaran STP Bandung yang tertuang dalam D1PA, sehingga keterbukaan untuk publik adalah kewenangan manajemen STP Bandung.

6. Sistem akuntansi yang digunakan berbasis kas (Cash Accounting) Enhaii Hotel wajib menyetorkan basil penjualannya kepada Negara sebagai Penerimaan Negara Bukan Pajak (PNBP) dengan Peraturan Pemerintah Republik Indonesia tentang jenis dan tarif PNBP setoran tersebut berupa uang tunai. 


\section{Efektivitas Pengelolaan Pendapatan dan Biaya}

Selanjutnya pembahasan tentang efektivitas pengelolaan pendapatan dan biaya sebagai dana operasional Enhaii Hotel berdasarkan wawancara dengan koordinator yang bersangkutan sebagai berikut:

1. Proses penjualan kamar dan pcnjualan makanan minuman yang dilakukan di Enhaii Hotel wajib disetor ke Kas Negara sebagai Penerimaan Negara Bukan Pajak (PNBP) sesuai dengan Peraturan Pemerintah Republik Indonesia Nomor 9 Tahun 2015 tentang Jenis dan Tarif Atas Jenis Penerimaan Negara Bukan Pajak yang berlaku pada Kementerian Pariwisata melalui Bendahara Penerima STP Bandung.

2. Mekanisme pembiayaan kegiatan operasional Enhaii Hotel dialokasikan pada anggaran yang berpusat dalam anggaran STP Bandung berupa Daftar Isian Pelaksanaan Anggaran (DIPA) dengan mengacu kepada peraturan dan kebijakan yang telah ditetapkan melalui otorisasi Pejabat Pembuat Komitmen (PPK) dan Kuasa Pengguna Anggaran (KPA).

\section{Kendala Akuntansi Sektor Publik Terhadap Efektivitas Pengelolaan Pendapatan dan Biaya}

Kendala-kendala yang terjadi atas pclaksanaan akuntansi sektor publik terhadap efektivitas pengelolaan pendapatan dan biaya, yaitu diantaranya :

1. Tujuan kegiatan bermotifkan nonprofit.

Proses penjualan produk Enhaii Hotel wajib disetor ke kas negara sebagai Penerimaan Negara Bukan Pajak (PNBP) sehingga Enhaii Hotel tidak dapat menggunakan hasil penjualan untuk biaya operasional, sedangkan biaya operasional Enhaii Hotel dianggarkan pada bagian Daftar Isian Kegiatan Anggaran (DIPA) STP Bandung, hal ini antara pendapatan dan biaya tidak dapat dipertemukan (matching principles), sehingga potensi penentian profit tidak optimal.

2. Sumber pendanaan untuk biaya operasional bersumber dari pemerintah.

Biaya operasional Enhaii Hotel bersumber pada anggaran pemerintah yang menginduk pada Anggaran (DIPA) STP Bandung, proses dan prosedur pengelolaan keuangan Enhaii Hotel berdasarkan mekanisme yang telah diatur dalam peraturan dan kebijakan pemerintah, sehingga kelancaran pengelolaan biaya Enhaii Hotel dinilai kurang optimal karena tidak dapat langsung menggunakan sumber dana tersebut karena terbentur dengan birokrasi aturan.

3. Kegiatan operasional dipertanggungjawabkan kepada masyarakat dan perlemen (DPR).

Enhaii Hotel merupakan bagian dari unit laboratorium praktek STP Bandung, sehingga segala jenis pertanggungjawaban kegiatan operasional Enhaii Hotel dilaporkan kepada manajemen STP Bandung tidak langsung kepada masyarakat dan parlemen, kendalanya Enhaii Hotel tidak dapat memberikan informasi pertanggungjawaban terutama potensi pendapatan dan efisiensi biaya secara langsung kepada masyarakat.

4. Struktur organisasi bersifat birokrasi dan kaku.

Enhaii Hotel memiliki keterbatasan dalam struktur organisasi, karena Enhaii Hotel merupakan bagian unit STP Bandung, sehingga keterbatasan ini mengakibatkan kalah bersaing dengan hotel lain yang mengakibatkan potensi pendapatan kurang maksimal. 
5. Karakteristik anggaran terbuka untuk publik.

Enhaii Hotel memiliki anggaran yang terpusat pada keuangan STP Bandung, sehingga transparansi kegiatan Enhaii Hotel tidak dapat dibuka ke publik kecuali seijin STP Bandung.

6. Sistem akuntansi yang digunakan berbasis kas (cash accounting).

Pendapatan atas penjualan di Enhaii Hotel harus disetor ke kas Negara berdasarkan kas basis, dan pengelolaan biaya sebagian kas basis, sehingga terkendala dalam pelaporan keuangan yang mencerminkan prinsip mempertemukan pendapatan dan biaya (matching principles).

\section{SIMPULAN}

Pelaksanaan akuntansi sektor publik berjalan dengan baik dan lancar maka pihak pengelola Enhaii Hotel hams memiliki rencana dan strategis yang baik dengan berdasarkan peraturan-peraturan yang berlaku serta dengan prosedur yang telah ditetapkan.

Pengelolaan pendapatan dan biaya agar efektif, maka prosedur setoran pendapatan pada kas negera harus sesuai dengan aturan yang telah ditetapkan dan tepat waktu, sedangkan biaya oprasional yang diajukan kepada pengguna anggaran harus direncakan dengan baik, yaitu prosedur pengajuan anggaran dan biaya harus direncanakan dengan baik sesuai dengan kegiatan yang terjadi pada operasional Enhaii Hotel, sehingga realisasi biaya dapat tercapai secara optimal.

Kendala-kendala yang terjadi pada kegiatan Enhaii Hotel dapat ditekan sekecil mungkin, maka pihak Enhaii Hotel hams dapat bersinergi dengan pengelola anggaran yaitu dengan pihak pejabat pembuat komitmen (PPK) yaitu pada saat pengajuan biaya operasional, pihak Enhaii Hotel hams memiliki rencana biaya yang akan terjadi dengan baik dan sesuai, sehingga dalam pengajuan biaya yang akan diajukan kepada PPK dapat terealisasi dengan baik dan lancar.

\section{DAFTAR REFERENSI}

Ahmad, Firdaus, dan Abdullah, Wasilah. 2012. Akuntansi Biaya. Edisi 3. Jakarta: Salemba Empat. Dannadi, Hamid. 2013. Metode Penelitian Pendidikan dan Sosial. Bandung: Alfab eta.

Mardiasmo. 2009. Akuntansi Sektor Publik. Yogyakarta: Andi.

Moleong, L.J. 2012. Metodologi Penelitian Kualitatif Edisi Revisi. Bandung: PT.Remaja Rosdakarya. Sugiyono. 2013. Metode Penelitian Kuantitatif Kualitatif dan R\&D. Bandung: Alfabeta.

Weygandt, Kimmel and Kieso. 2011. Intermediate Accounting, Edisi 12 by: Erlangga. PMK No. 190/PMK.05/2012 tentang Daftar isian Pelaksanaan Anggaran (DIPA) Peraturan Pemerintah Republik Indonesia Nomor 9 Tahun 2015 tentang Jenis dan Tarif atas Jenis Penerimaan Negara Bukan Pajak Yang Berlaku pada Kementerian Pariwisata. Peraturan Menteri Keuangan RI Nomor 94/PMK.02/2013 tentang Pedoman Umum R KA-KIL. Peraturan Pemerintah No. 24 tahun 2005 tentang Standar Akuntansi Pemerintahan. Peraturan Pemerintah No. 71 Tahun 2010 tentang Standar akuntansi Pemerintah. 